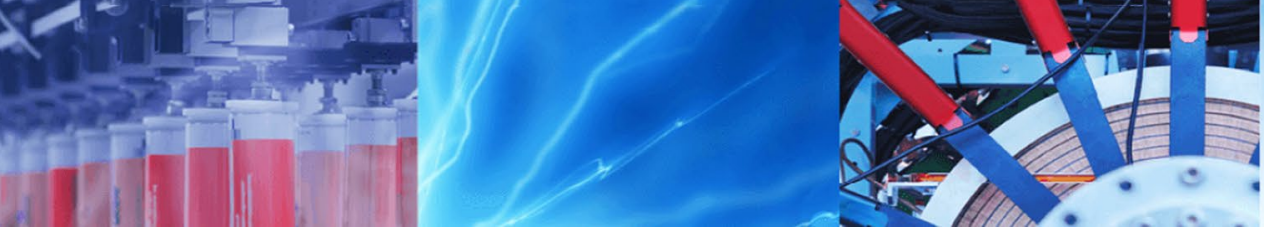

Research Article

\title{
Mineralogical, geochemical characterization and application of an alluvial clay material
}

\author{
V. Y. Katte ${ }^{1} \cdot$ F. Ngapgue ${ }^{2}$ J. M. Tsang ${ }^{3}$
}

(c) Springer Nature Switzerland AG 2019

\begin{abstract}
Field surveys were conducted in which six samples of clay were collected and characterized. The results of the mineralogical analysis, carried out by X-ray diffractometry on total powder and on the clay powder reveal the presence of kaolinite, illite and chlorite clay minerals, with the clay color predominantly reddish. The non-clay minerals identified were quartz, goethite, gibbsite, feldspar, hematite and anatase. The geochemical composition obtained by $\mathrm{X}$-ray fluorescence shows that the material of the study area are richer in $\mathrm{SiO}_{2}, \mathrm{Al}_{2} \mathrm{O}_{3}$ and $\mathrm{Fe}_{2} \mathrm{O}_{3}$. The $\mathrm{SiO}_{2} / \mathrm{Al}_{2} \mathrm{O}_{3}$ of all the samples were greater than 1 indicative of kaolinitic clays while $\mathrm{Fe}_{2} \mathrm{O}_{3} / \mathrm{Al}_{2} \mathrm{O}_{3}$ are less than 1 indicative of the presence of iron based compounds. Also low contents of $\mathrm{TiO}_{2}, \mathrm{MgO}, \mathrm{CaO}, \mathrm{MnO}, \mathrm{NaO}, \mathrm{P}_{2} \mathrm{O}_{5}$ and $\mathrm{K}_{2} \mathrm{O}$ were also revealed. The different results obtained show that the process of meteoric weathering is the origin of the genesis of these clays. The physical analysis consisted in obtaining the particle size distribution and the Atterberg limits. The proportions of sand vary between 14 and 20\%; silts between 18 and $28 \%$ and finally clays between 52 and $65 \%$ with the clays belonging to two textural classes namely fine clays and clays. The Atterberg limits indicates that the materials are plastic with plasticity indices between 30 and $34.1 \%$. Based upon the Winkler diagram to ascertain their ceramic uses, four samples were disqualified for solid brick manufacture while two samples were recommended for masonry tiles and bricks.
\end{abstract}

Keywords Clay materials · Mineralogical analysis · Geochemical composition · Physical analysis · Ceramic purposes

\section{Introduction}

Clays make up one of the most abundant industrial raw materials on the surface of the earth constituting about $90 \%$ of the earth's bulk [46]. These clay minerals are mainly detrital and are derived from physical or chemical alteration of pre-existing rocks [30]. They are rich in aluminum and silicon and therefore have been utilized in the construction industry for the production of bricks and ceramics and they also find wide application in other manufacturing industries such as pharmaceuticals and cosmetics. It is very probable that the sphere of clay utilization will continue to broaden, therefore exploring and cataloging the clay deposits of any locality will significantly contribute to potential socio-economic development. Thus far Njoya et al. [41] have presented an exhaustive summary comprising the location, clay types and possible utilization of some Cameroon clay deposits, though more exploration is crucial as well as the creation of ventures for their utilization. More than thirty five years of research carried out by some researchers lends credence to the enormous potentials for industrial utilization and applications of argillaceous materials. For example, Njopwouo and Wandji $[37,40]$ valorizes hallosyte, cosmetic applications such talc is proposed by Nkoumbou et al. [38, 39]. Meanwhile for baked clay products, a host of researchers such as Diko et al. [5], Djangang

$\triangle$ V. Y. Katte, ykatte@yahoo.com | 'Department of Civil Engineering and Architecture, National Higher Polytechnic Institute (NAHPI), The University of Bamenda, P.O. Box 39, Bambili, NWR, Cameroon. ${ }^{2}$ Department of Civil Engineering, Fotso Victor University Institute of Technology (IUTFV), University of Dschang, P.O. Box 134, Bandjoun, Cameroon. ${ }^{3}$ Department of Earth Sciences, Faculty of Science, University of Dschang, P.O. Box 67, Dschang, Cameroon. 
et al. [6-10], Elimbi et al. [13, 15, 16, 17], Elimbi and Njopwouo [14], Kamseu et al. [18-20, 22], Leonelli et al. [27], Melo et al. [29], Pialy et al. [45]. The attempts at formulating geopolymer cements based on clays rich in kaolinites were carried out by Kamseu et al. [21], Lemougna et al. [26], Obonyo et al. [44] and Tchakoute et al. [48, 49]. Clays have also been utilized as a mineral filler in rubber reinforcement and as a catalyst in the polymerization of styrene [33-36] and, most recently, in the production of composite films utilizing cassava starch and kaolin [28]. With a rich repertoire of the potentials of clay utilization for industrial concerns so far gathered, exploration of more deposits is still necessary in order to catalogue and create an inventory of areas with some valuable quantities of clay deposits that could be harnessed for industrial applications. Consequently, the aim of this study is to broaden this repertoire by characterizing the clay of Baboutcheu-Ngaleu.

\section{Description of study site}

Baboutcheu-Galeu has a surface area of $18 \mathrm{~km}^{2}$ and is one of six villages located in Bafang Subdivision between latitude $5^{\circ} 05^{\prime} \mathrm{N}$ and $5^{\circ} 08^{\prime} \mathrm{N}$ of and longitude $10^{\circ} 09^{\prime} \mathrm{E}$ and $10^{\circ} 12^{\prime} \mathrm{E}$ of the Upper-Nkam Division of the West Region of Cameroon. Baboutcheu-Ngaleu village is bordered to the north by Baboné, to the south and east by Bakassa and to the west by Bakondji, Bakou and Fondjanti as shown in Fig. 1a. It has a tropical climate with two alternating seasons: a rainy season from March to November and a dry season from December to February. The lowest average rainfall is recorded in December with $9 \mathrm{~mm}$ of rainfall, while the month of September is the wettest with an average rainfall of $366 \mathrm{~mm}$. The month of March is the hottest month with a temperature of $22.2^{\circ} \mathrm{C}$ and the month of July the coldest with a temperature of $19.6^{\circ} \mathrm{C}$. The annual average rainfall in this zone is $2085 \mathrm{~mm}$ with an average temperature of $21.0^{\circ} \mathrm{C}$.

The study site falls within the highlands of western Cameroon and at an altitude of between 1320 and $1522 \mathrm{~m}$. They form a vast chain of highlands (Bamoun plateau, Bambouto, Bamenda, Oku and Bana mountains) and plains (Noun and Ndop), consisting of superficial formations (alluviums, eluvions and alterites), volcanic formations (basalts, trachytes, phonolites, rhyolites tuffs, ignimbrites) and granito-gneissic basement [43]. The town of Bafang is located $14 \mathrm{~km}$ from the volcanoplutonic complex of Bana [23] comprising basalts (composed of plagioclase (labrador, bytownite), pyroxene, and olivine) and anatexites as shown in the geologic map in Fig. 1b. The landscape consists of steep slopes that are covered with shrubs and trees and in most cases $\mathbf{a}$

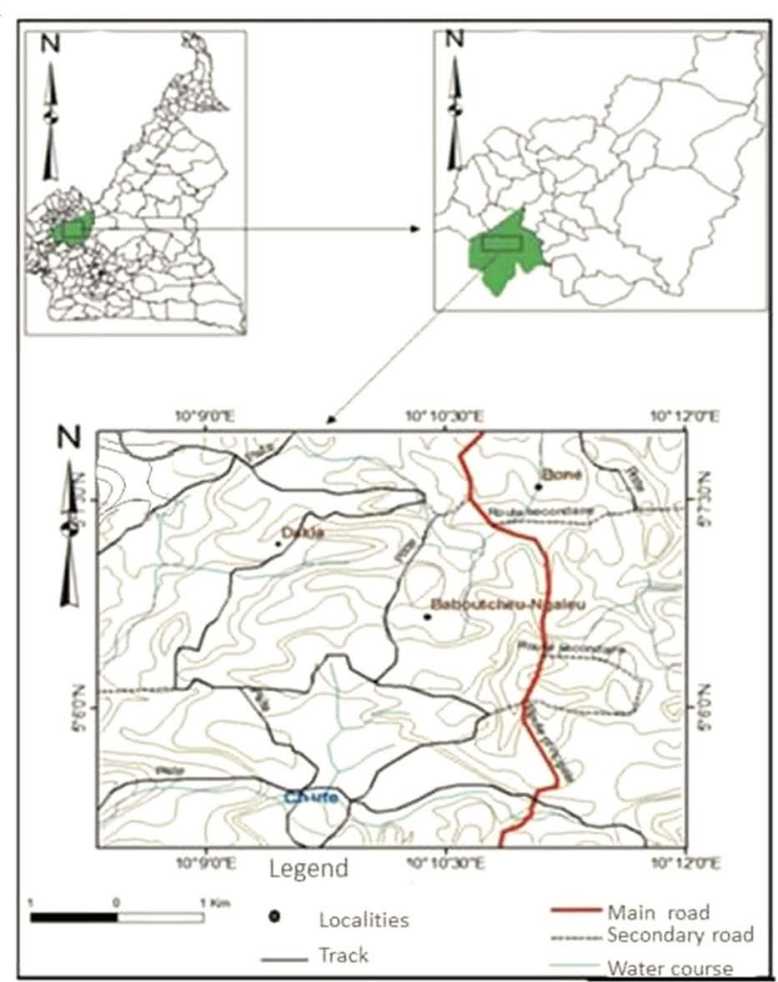

b

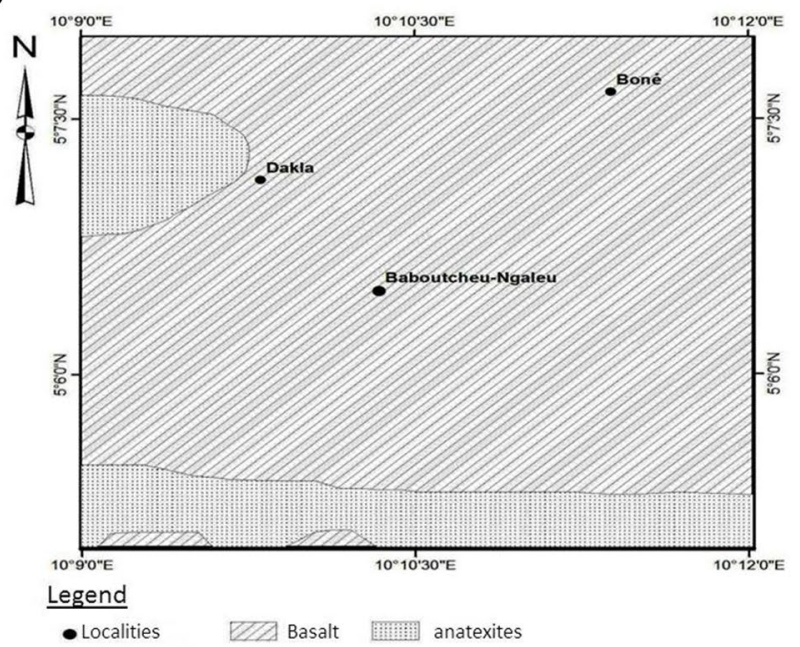

Fig. 1 a Location map of the study area scale 1/50,000. b Geologic map of study area. Extract of the geologic map of the Federal Republic of Cameroon. Douala-west. [12]

evidence of human tempering exists most notably due to farming and road construction activities. There are two types of soils: namely, the lowland soils (hydromorphs) which are rich in organic matter and often flooded during the rainy season and the mountain soils which are ferraltic, silty clays with some lateritic hard pans in certain areas. 


\section{Materials and methods}

\subsection{Clay estimation and sampling}

Three field outings were carried out with the first one being a reconnaissance survey which enabled the identification of the presence of potential sampling sites having the clay cones as well as the textural evaluation of the clay along road cut slopes. During the second visit, two trial pits were made at the foot of the hill of size $4 \mathrm{~m} \times 2 \mathrm{~m} \times 8 \mathrm{~m}$. On the third visit the topo sequential method was used, whereby five other similar trial pits were established on site consisting of one between the bottom of the hill and the hill crest, then one at the hill crest. Also on the descending side of the hill, one trial pit was dug at the mid distance again between the hill crest and the foot of the hill. This method enabled the proper realization of the vertical variation of the facies along the slope and along the walls of the dug trial pits. Sample collection was done on the basis of the variation of the color of the facies with this depth. Thus, a sample was taken at the top, two samples each collected from the trial pits on each side of the slope, giving a total of 19 samples collected. The morpho-structural description of the profiles focused on the main parameters that are: the limit between the facies, the thicknesses of the different facies, the depth and the various elements figured out. The macroscopic description of the samples took into account the color and the texture. In the field, the texture was determined by touch and color thanks to the Munsell [32] color code.

\subsection{Clay preparation and characterization}

\subsubsection{XRD analysis}

The X-ray diffraction was carried out at the University of Liege in Belgium using a Brucker D8-Advance type diffractometer (copper Ka1 radiation $\lambda=1.5418 \AA, V=40 \mathrm{kV}$, $\mathrm{I}=30 \mathrm{~mA}$ ). The measurements were carried out in the range $2 \theta$ from $2^{\circ}$ to $45^{\circ} 2 \theta$ for non-oriented powders and $2^{\circ}-30^{\circ} 2 \theta$ for oriented blades following the procedures of Moore and Reynolds [31]. This enabled the mineralogical content of the clays to be obtained by the interpretation of the mineral phases using Eva software.

\subsubsection{XRF analysis}

The chemical composition of 19 samples were obtained by X-ray Fluorescence Spectroscopy (XRF) with an ARL ${ }^{\text {TM }}$ PERFORM ${ }^{\prime} X$ spectrometer of the University of Liège.

\subsubsection{Particle size analysis}

The grain size distribution was carried out by wet sieving of the fraction $>80 \mu \mathrm{m}$ and sedimentation analysis for fractions between 80 and $2 \mu \mathrm{m}$ following ASTM norms D-422 [1], while the Atterberg limits were obtained by the Casagrande method following ASTM D-4318 [2].

\section{Results and discussion}

\subsection{Morphostructural descriptions of the trial pits}

The morpho-structural description of the trial pits was based on parameters such as the thickness of the different facies, the boundary between the facies, the depth and the elements encountered.

Trial pit $\mathrm{P}_{1}$, was dug at the bottom of the slope at a depth of $130 \mathrm{~m}$ (Fig. 2) with the coordinates being $\left(05^{\circ} 07^{\prime} 05.1^{\prime \prime}\right.$ of latitude, $10^{\circ} 09^{\prime} 03.6^{\prime \prime}$ east of longitude and at an altitude of $1262 \mathrm{~m}$ ). It has three well differentiated levels: top soil was $15 \mathrm{~cm}$ thick and dark in color, containing roots more than $2 \mathrm{~cm}$ in diameter. A yellowish-red (5YR 3/4yellowish red) clayish facies level followed, with a thickness of $20 \mathrm{~cm}$ and clayish texture with multiple dark gray (5YR 3/1) and reddish-yellow (5YR 5/8) patches. The third level has a lightly red (10 R 5/4) clay-colored facies, $100 \mathrm{~cm}$ thick with a clayish texture and with roots up to $2 \mathrm{~cm}$ in
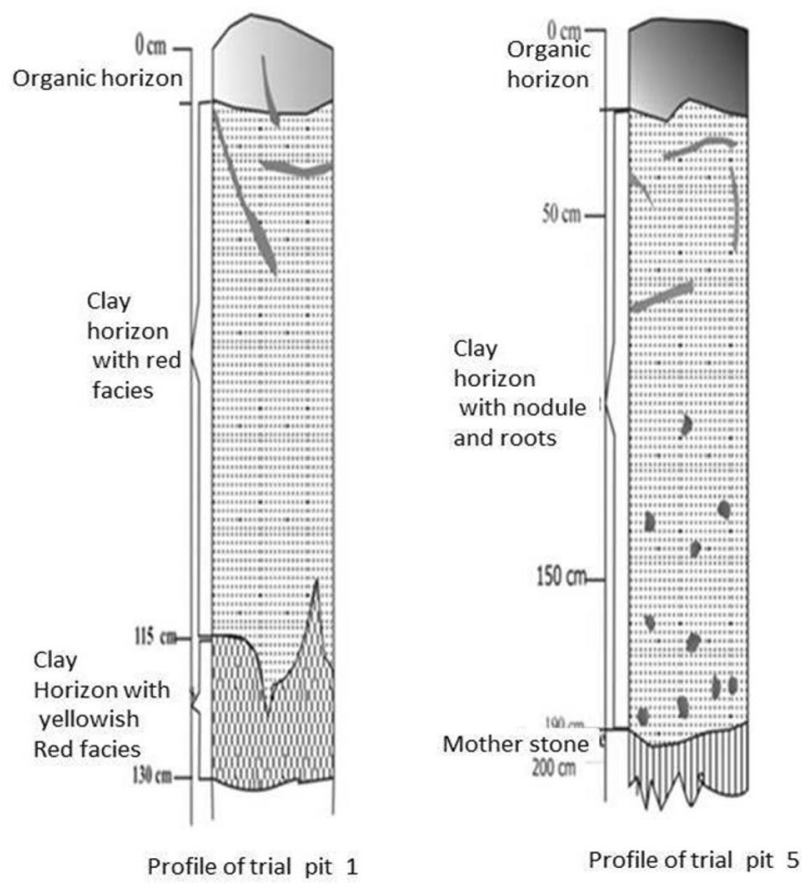

Fig. 2 Trial pits profiles at the bottom of slopes 
diameter. The boundaries between the two facies are not clearly distinctive.

Trial pit $\mathrm{P}_{5}$, was realized at the bottom of the slope opposite trial pit $\mathrm{P}_{1}$ at the geographical coordinates $\left(05^{\circ} 07^{\prime} 02^{\prime \prime}\right.$ of latitude, $10^{\circ} 09^{\prime} 08^{\prime \prime}$ of longitude and at an altitude of $1246 \mathrm{~m}$ ), and to a depth of $200 \mathrm{~cm}$ as shown in Fig. 2. Here, we note the presence of two levels with the first layer made up of topsoil having a small thickness $(5 \mathrm{~cm})$ and having roots of average diameter. The second layer is a clayish facie of clayish-silt texture, $170 \mathrm{~cm}$ thick and reddish-yellow color (7.5YR 6/8 reddish-yellow). Here we also note the presence of nodules with a red to yellow color, blocks with diameters up to $4 \mathrm{~cm}$ as well as roots of very small diameter.

Trial pit $P_{2}$, was dug at the median of the slope between the bottom and the crest with the geographic coordinates $\left(05^{\circ} 07^{\prime} 05.1^{\prime \prime}\right.$ of latitude, $10^{\circ} 09^{\prime} 03.6^{\prime \prime} \mathrm{E}$ of eastern longitude and at an altitude of $1262 \mathrm{~m}$ ). The trial pit is $550 \mathrm{~cm}$ deep (Fig. 3) and is made up of three horizons, consisting of topsoil, $20 \mathrm{~cm}$ thick containing small diameter roots. The mineral horizon is differentiated into two levels. The level with clay facies is light red (10R 6/8 light red) and is $450 \mathrm{~cm}$ thick with a clayey-silt texture. At this level we note the presence of nodules of about $20 \mathrm{~cm}$ thick with diameters of between $0.5 \mathrm{~mm}$ and $0.5 \mathrm{~cm}$, as well as roots of diameter relatively less than $1 \mathrm{~cm}$. The second level consists of an array of gray color and extends to a depth of $70 \mathrm{~cm}$.

Trial pit $\mathrm{P}_{4}$, was dug at the mid distance between the crest and the bottom on the descending side of the hill at the geographical coordinates of latitude $05^{\circ} 07^{\prime} 05^{\prime \prime}$ and
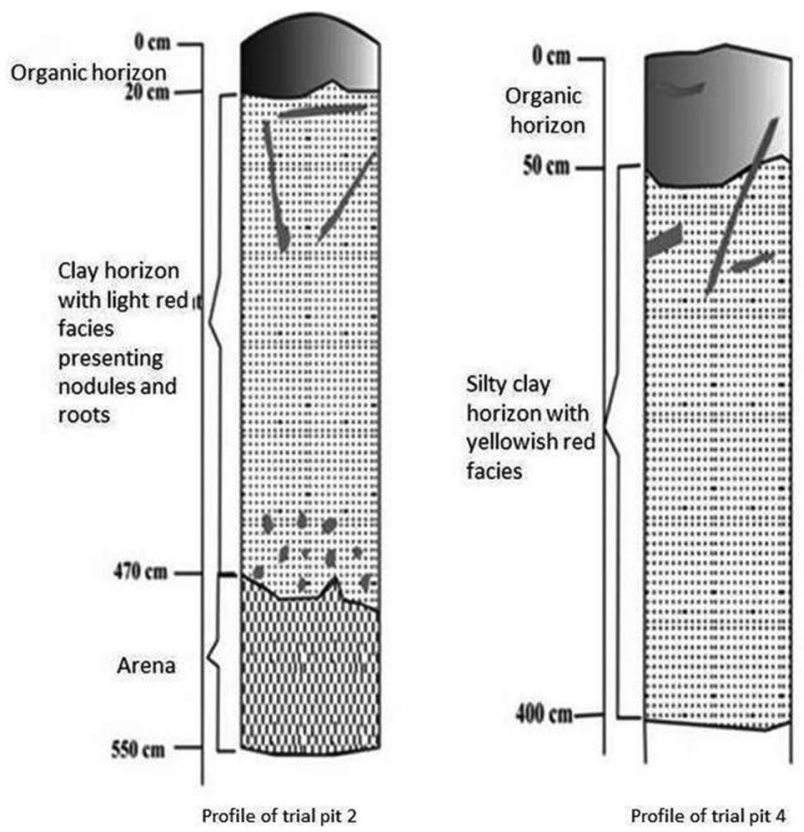

Fig. 3 Profile of trial pits at the median of slopes longitude $10^{\circ} 09^{\prime} 01^{\prime \prime} \mathrm{E}$ and at an altitude of $1255 \mathrm{~m}$. It has a depth of $400 \mathrm{~cm}$ (Fig. 3) and is made up of two levels with a dark-colored topsoil, $50 \mathrm{~cm}$ thick containing roots up to $2 \mathrm{~cm}$ in size. The facies level is yellowish red (5YR 5/8 yellowish-red), $340 \mathrm{~cm}$ thick with a silty clay texture.

Trial pit $\mathrm{P}_{3}$ was dug at the crest of the hill to a depth of $800 \mathrm{~cm}$ (Fig. 4) with the geographical coordinates $\left(05^{\circ} 07^{\prime} 03.6^{\prime \prime}\right.$ of latitudes North, $10^{\circ} 09^{\prime} 03.2^{\prime \prime}$ of longitude East and at an altitude of $1289 \mathrm{~m}$ ). The material consists of a silty clay texture of a light red color (10R $6 / 8$ light red) with a thickness of $976 \mathrm{~cm}$. We also notice the presence of small roots in this horizon. A summary of the profile characteristics of each of the trial pits is shown on Table 1 while Fig. 5 shows the facies of samples collected.

\subsection{Particle size analysis}

The results of the particle size analysis show that the clay materials studied consist of three fractions of varying proportions. Table 2 shows that the proportions of sand vary between 14 and 20\%; silts between 18 and $28 \%$ and finally clays between 52 and $65 \%$. In particular, the E6 sample is distinguished by its high value in sand content (20\%), and (28\%) in the silt content. Sample E2

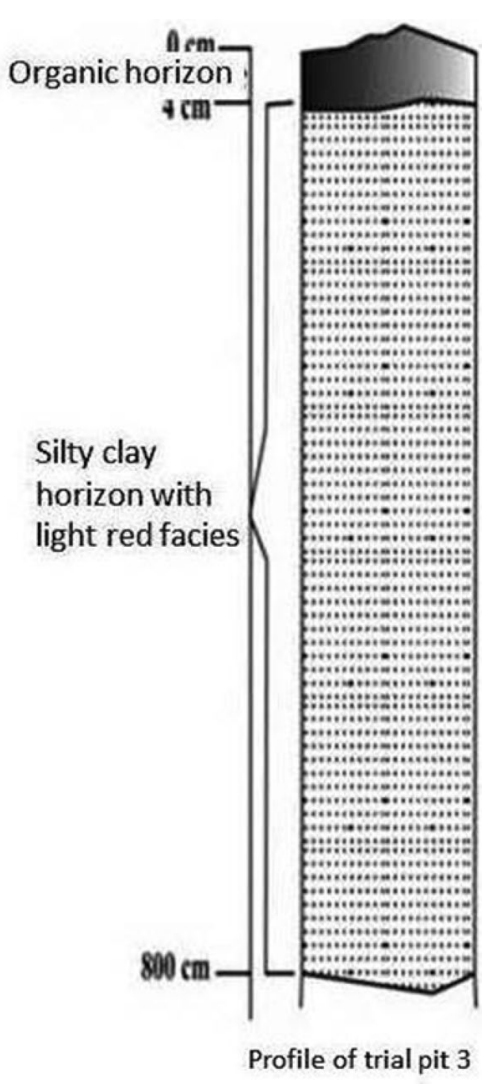

Fig. 4 Profile of trial pit $P_{3}$ located at the top of the slope 
Table 1 Summary of morpho-structural and macroscopic characteristics of samples from the trial pits

\begin{tabular}{|c|c|c|c|c|c|c|}
\hline Trial pits & Coordinates & Code & Thickness (cm) & Texture & Color & Observations \\
\hline \multirow[t]{2}{*}{1} & $\begin{array}{l}\mathrm{N}: 05^{\circ} 07^{\prime} 04,4^{\prime \prime} \\
\mathrm{E}: 10^{\circ} 09^{\prime} 05,6^{\prime \prime}\end{array}$ & E1 & 20 & \multirow[t]{2}{*}{ Clayey } & $\begin{array}{l}\text { Yellowish red (5YR 3/4 yellow- } \\
\text { ish red) }\end{array}$ & \multirow{2}{*}{$\begin{array}{l}\text { Patches of variable color (5YR } \\
3 / 1 \text { very dark gray, and } 5 Y R \\
5 / 8 \text { reddish-yellow), } \\
\text { Contains roots of up to } 2 \mathrm{~cm}\end{array}$} \\
\hline & Altitude: $1262 \mathrm{~m}$ & E2 & 100 & & Light red (10 R 5/4 light red) & \\
\hline 2 & $\begin{array}{l}\text { N: } 05^{\circ} 07^{\prime} 05,1^{\prime \prime} \mathrm{E}: 10^{\circ} 09^{\prime} 03,6^{\prime \prime} \\
\text { Altitude: } 1262 \mathrm{~m}\end{array}$ & E3 & 550 & Clayey-silt & Light red (10R 6/8 light red) & $\begin{array}{l}\text { Nodules are present with } \\
\text { diameters ranging from } \\
(0.5 \mathrm{~mm}-0.5 \mathrm{~cm}) \text { as well as } \\
\text { roots }<1 \mathrm{~cm}\end{array}$ \\
\hline 3 & $\begin{array}{l}\mathrm{N}: 05^{\circ} 07^{\prime} 03,6^{\prime \prime} \\
\mathrm{E}: 10^{\circ} 09^{\prime} 03,2^{\prime \prime} \\
\text { Altitude: } 1289 \mathrm{~m}\end{array}$ & E4 & 796 & Clayey-silt & Light red (10R 6/8 light red) & $\begin{array}{l}\text { The presence of small roots is } \\
\text { noted }\end{array}$ \\
\hline 4 & $\begin{array}{l}\mathrm{N}: 05^{\circ} 07^{\prime} 05^{\prime \prime} \\
\mathrm{E}: 10^{\circ} 09^{\prime} 01^{\prime \prime} \\
\text { Altitude: } 1255 \mathrm{~m}\end{array}$ & E5 & 340 & Silty-clay & $\begin{array}{l}\text { Yellowish red (5YR } 5 / 8 \text { yellow- } \\
\text { ish red) }\end{array}$ & Having roots of diameter $>2 \mathrm{~cm}$ \\
\hline 5 & $\begin{array}{l}\mathrm{N}: 05^{\circ} 07^{\prime} 02^{\prime \prime} \\
\mathrm{E}: 10^{\circ} 09^{\prime} 08^{\prime \prime} \\
\text { Altitude: } 1246 \mathrm{~m}\end{array}$ & E6 & 170 & Clayey-silt & $\begin{array}{l}\text { Reddish yellow (7.5YR 6/8 red- } \\
\text { dish yellow) }\end{array}$ & $\begin{array}{l}\text { Nodules with red to yellow } \\
\text { color and blocks of diameter } \\
4 \mathrm{~cm} \text { as well as roots of very } \\
\text { small diameter }\end{array}$ \\
\hline
\end{tabular}
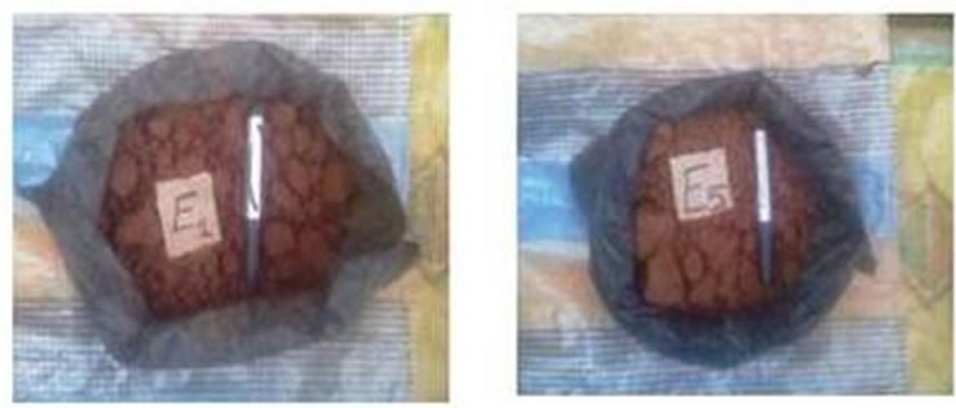

a Facies of reddish yellow clay
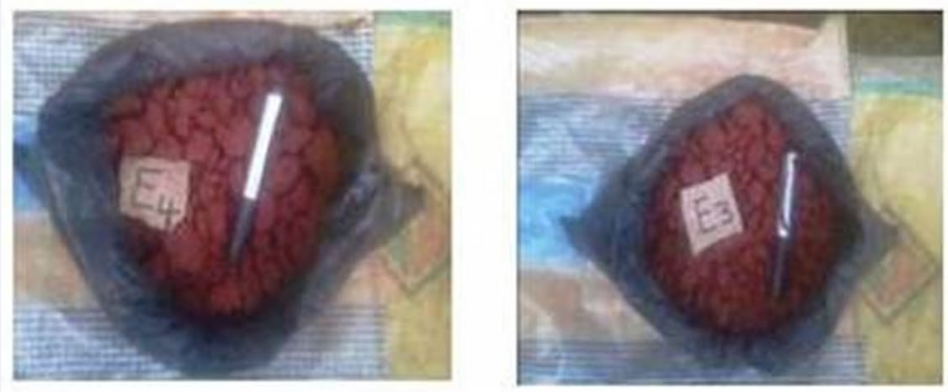

c Facies of bright red clay

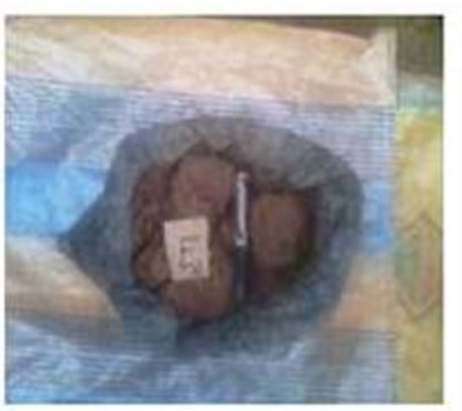

b Facies of slightly red clay

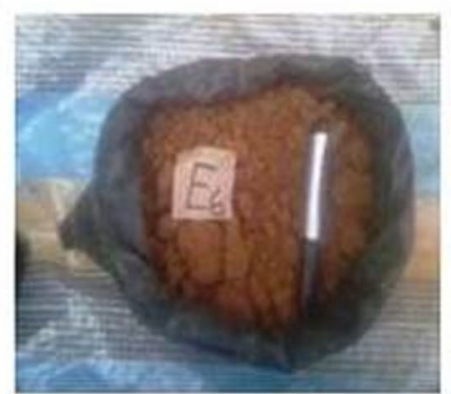

d Facies of yellowish red clay

Fig. 5 Clay facies obtained from the study site

Table 2 Particle size analysis of analyzed samples

\begin{tabular}{lllllll}
\hline Fractions & E1 & E2 & E3 & E4 & E5 & E6 \\
\hline Sand (\%) & 16 & 17 & 18 & 14 & 19 & 20 \\
Silt (\%) & 20 & 18 & 22 & 24 & 27 & 28 \\
Clay (\%) & 64 & 65 & 60 & 62 & 54 & 52 \\
\hline
\end{tabular}


has a high clay value of (65\%), while its sand and silt values are $(17 \%)$ and $(18 \%)$ respectively. Figure 6 shows the variation of the different size classes according to the different topo sequential profiles observed. It follows from this figure that the samples of the trial pit $P_{1}$ have the highest clay content, while those of trial pit $\mathrm{P}_{5}$ have a high proportion of sand and silt. The various samples studied were plotted on the Durand diagram [11] as shown in Fig. 7 reveal that the clays belong to two textural classes namely fine clays and clays. A summary of the consistency limits for each of the analyzed samples are presented on Table 3 This table shows that the plasticity indices of the samples are between 30 and $34.1 \%$. These materials have higher liquid limits in sample E1 $(L L=92.1 \%)$ and lower in sample E3 $(L L=72.1 \%)$. Sample E3 has the lowest ( $P L=42.1 \%$ ) while the sample $\mathrm{E} 2$ has the highest value $(\mathrm{PL}=58.8 \%)$. The plasticity index is obtained as the difference between the liquid limit and the plastic limit for each sample. It should be noted that despite the slight differences between these different values, these clay samples remain almost identical.
Fig. 6 Variation of grain size fractions in each trial pit

Fig. 7 Textural diagram according to Durand [11]
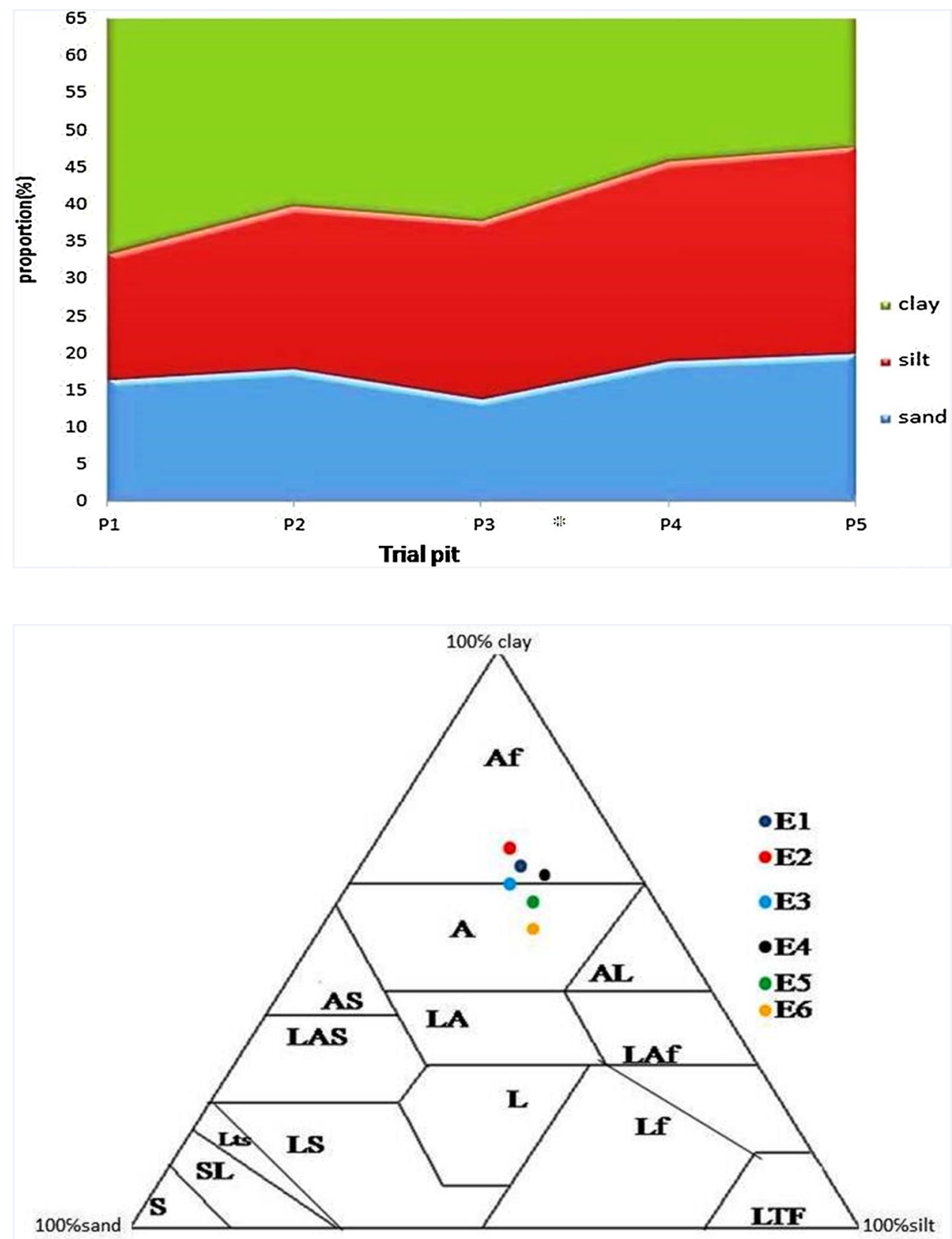

Af- fine clay, LA-fine silty clay, L- silt, AL-silty clay, LAS-silty sandy clay, LtS-very sandy silt, ASsandy clay, Laf-fine silty clay, LS-silty sand, A-clay, LfA-fine silty clay, Lf- fine silt, Ltf-very fine silt, Ssand, SL-silty sand 
Table 3 Atterberg limits of different samples

\begin{tabular}{lllllll}
\hline & E1 & E2 & E3 & E4 & E5 & E6 \\
\hline LL (\%) & 92.1 & 91.9 & 72.1 & 75.2 & 83 & 83.7 \\
PL (\%) & 58.5 & 58.8 & 42.1 & 42.9 & 48.9 & 49.8 \\
PI (\%) & 33.6 & 33.1 & 30 & 32.3 & 34.1 & 33.8 \\
Description & Plastic & Plastic & Plastic & Plastic & Plastic & Plastic \\
\hline
\end{tabular}

$\mathrm{PI}=\mathrm{LL}-\mathrm{PL}$

$L L$ - liquid limit, $P L$ - plastic limit and $P I$ - plasticity index

\section{Mineralogy}

The various diffractographs resulting from XRD analysis of the various samples carried out on the total powder, clay fraction, clay fraction subjected to ethylene glycol and clay fraction subjected to a heat treatment of $500^{\circ}$ is shown in Fig. 8. The X-ray spectra and the results of semi-quantification carried out on total powder show that the clay materials of the study area are made of the following in descending order of importance of: $45.21-60.70 \%$ of total clay with a peak at $4.47 \AA \bar{\AA}, 17.16-21.76 \%$ of goethite, with a peak of $4.14 \AA \bar{A}, 2.27-10.22 \%$ of quartz with peaks of $4.37 \AA$, $4.25 \AA$ and $3.34 \AA$. Then $4.35-13.37 \%$ of feldspar with peaks

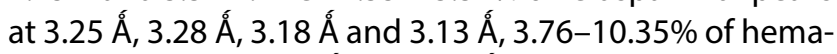
tite with peaks at $2.70 \AA \bar{\AA}$ and $2.70 \AA \AA, 0.34-7.43 \%$ of gibbsite with a peak of $4.85 \AA$ Á and finally $1.75-3.14 \%$ of anatase with a peak of 3.57 Á. The proportions of the different minerals present in the samples is given on Table 4.

The XRD performed on the clay fraction gives the spectra of different minerals present in the fine fraction of the studied clay materials (E1, E2, E3, E4, E5 and E6), with their various spectra shown in Fig. 9 and Table 5 gives the proportion of the various minerals in the fine fraction. The diffractographs of all the samples show a peak at $7.14 \AA$ which persists both in normal and in ethylene glycol. This peak disappears or flattens after heating. We also note a peak at $14 \AA$ having the same behavior as that at a peak of $7.14 \AA$. In sample $E 1$, there is a peak at $10 \AA$ which persists in normal, ethylene glycol and on the heat treated samples. The XRD associated with the semi-quantification for all the analyzed samples makes it possible to identify the following $45.83-100 \%$ of kaolinite with a peak at $7.17 \AA$, $0-13.77 \%$ of chlorite with a peak at 14.11 Á and $0-40.47 \%$ of illite with a peak at $10 \AA$ Á. It follows from this semiquantification that kaolinite is the most abundant mineral of the clay fraction. The reason for this is attributed to monosialitic hydrolytic alteration that would have affected pre-existing surrounding rocks [12]. This also agrees with Bitom [3] that the abundance of kaolinite could be related to the resisilification of the gibbsite following the equation

$2 \mathrm{Al}(\mathrm{OH})_{3}+\mathrm{SiO}_{2} \overrightarrow{\text { Resilification }} \mathrm{Al}_{2} \mathrm{Si}(\mathrm{OH})_{4} \mathrm{O}_{5}$
The gibbsite identified by XRD in the samples studied could be related to an allitizing hydrolytic alteration or the desilification of kaolinite. Bomeni [4] who carried out a similar work at Babouantou shows that the presence of feldspars would indicate the absence of alkali and alkaline earth metals resulting from leaching. Upon focusing on these remarks, it will be judicious to conclude that the gibbsite present in the clay materials of BaboutcheuNgaleu would not have resulted from a hydrolysis of allithising type but from the de-silicification of the kaolinite. Bitom [3] also proposes an equation to understand this de-silification reaction.

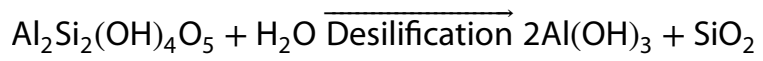

The goethite found in the study site is believed to be related to hydrolytic alteration of alitite type, because the average value of precipitation ( 2085 milliliters) shows that the study site is well watered. In addition the high altitude $(1500 \mathrm{~m})$ is also a parameter which cannot be ignored. The presence of feldspars at a low proportions may be justified by the fact that the area is well drained. The presence of illite in the samples indicates a hydrolytic alteration climate of the bissiallitizing type that initially affects feldspar minerals such as orthoclase or a neoformed mineral such as kaolinite [4]. The reason being that the alteration of the kaolinite present in the samples is the origin of the formation of illite. The presence of illite could confirm the process of bisillitisation. Based on the range of minerals obtained (gibbsite, goethite, hematite, kaolinite, chlorite and illite), it would be logical to infer that the clay materials of the study area are as a result of an hydrolytic alteration in a supergene medium combining allitization, monosilitization and bis-aluminization.

\section{Geochemistry}

The chemical composition of major elements expressed as percentage of oxide, as well as the loss on ignition is presented on Table 6. It follows from this table that: Silica $\left(\mathrm{SiO}_{2}\right)$ and alumina $\left(\mathrm{Al}_{2} \mathrm{O}_{3}\right)$ are the most abundant oxides 
Fig. 8 Diffractogram of samples E1, E2, E3, E4, E5 and E6 obtained by XRD on total powder

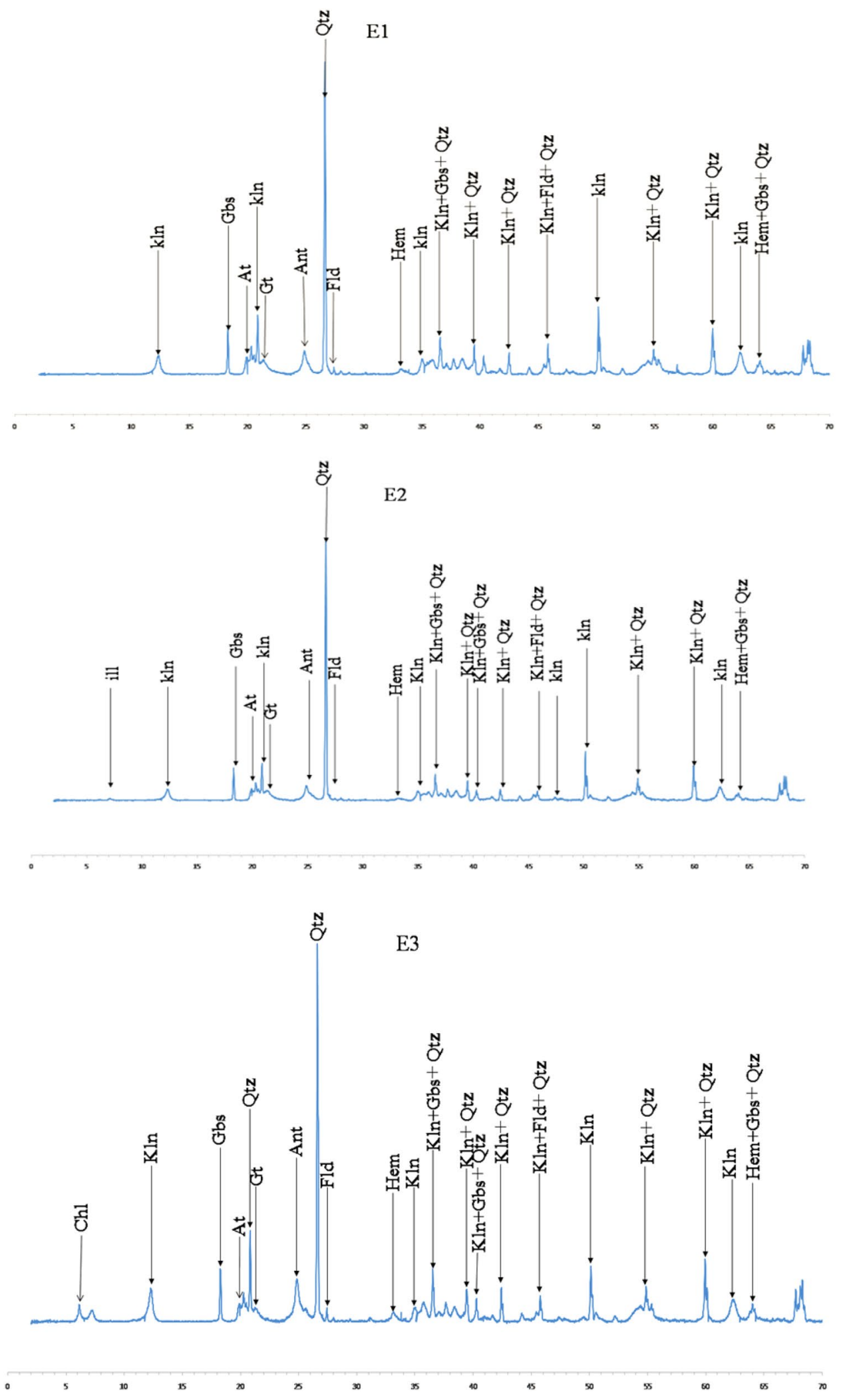

(46.14\%). In addition, the $\mathrm{Fe}_{2} \mathrm{O}_{3}$ contents are high in all the samples.

The values of $\mathrm{K}_{2} \mathrm{O}, \mathrm{NaO}, \mathrm{CaO}, \mathrm{P}_{2} \mathrm{O}_{5}, \mathrm{MgO}, \mathrm{MnO}$ are relatively low to trace. Indeed, the sample E1 shows 
Fig. 8 (continued)
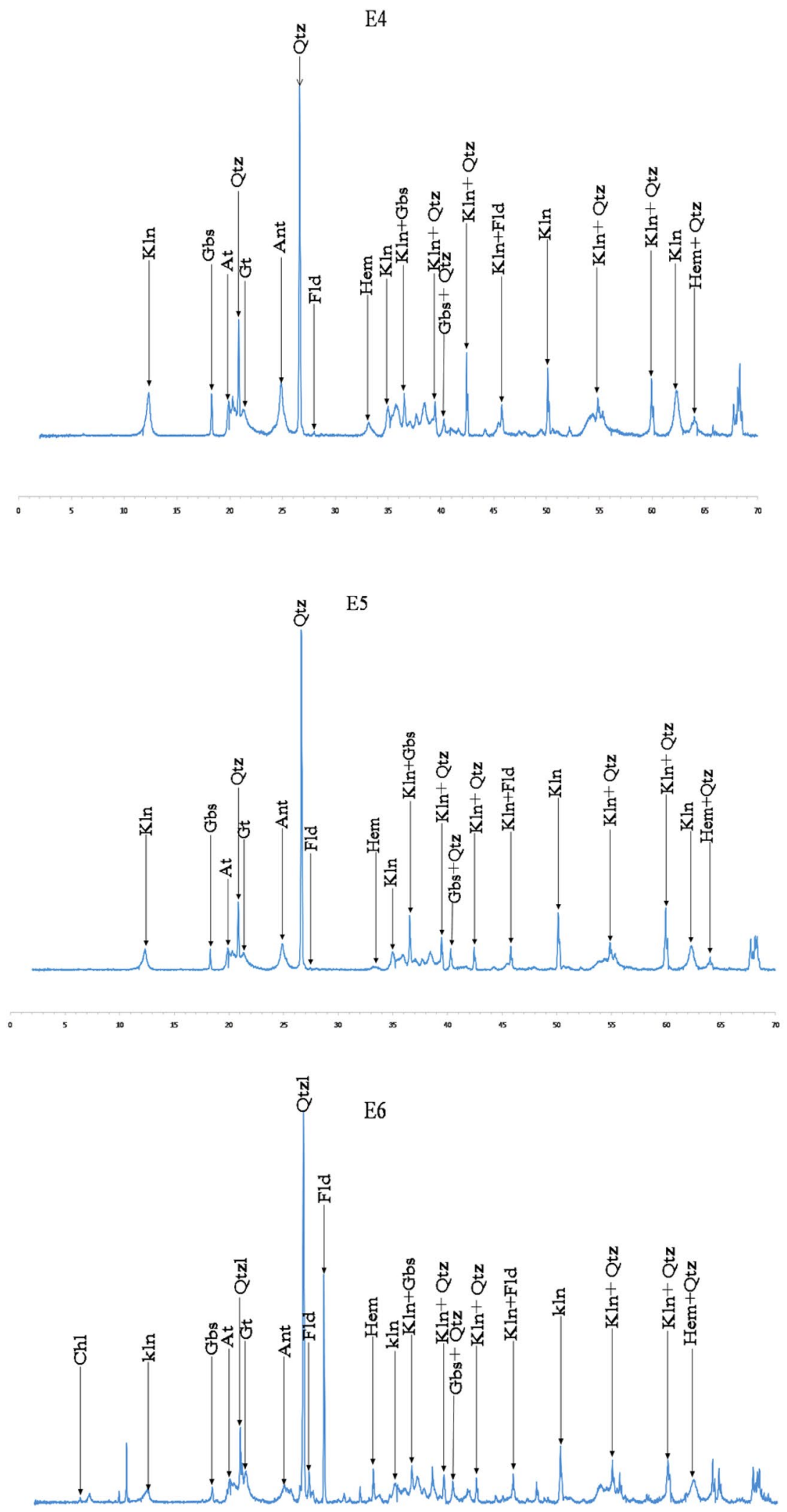
Table 4 Composition of various minerals obtained from total powder

\begin{tabular}{llllllll}
\hline Sample & Clay & Gibbsite & Goethite & Hematite & Anatase & Quartz & Feldspar \\
\hline E1 & 54.75 & 7.43 & 19.16 & 5.21 & 3.14 & 2.74 & 7.54 \\
E2 & 54.25 & 7.3 & 18.99 & 3.76 & 2.64 & 7.23 & 5.83 \\
E3 & 49.03 & 6.21 & 17.16 & 6.8 & 1.79 & 10.22 & 8.79 \\
E4 & 60.7 & 0.34 & 17.7 & 5.47 & 2.58 & 8.85 & 4.35 \\
E5 & 56.06 & 3.42 & 19.62 & 4 & 2.29 & 8.81 & 5.17 \\
E6 & 45.21 & 1.34 & 21.76 & 10.35 & 1.75 & 6.22 & 13.37 \\
\hline
\end{tabular}

zero values in $\mathrm{K}_{2} \mathrm{O}$. Similarly, it should be noted that $\mathrm{NaO}$ appears to be the least occurring oxide in all the samples because its values are totally zero in samples $\mathrm{E} 1, \mathrm{E} 2, \mathrm{E} 4$ and $\mathrm{E} 6$. The low levels of $\mathrm{MgO}, \mathrm{MnO}, \mathrm{CaO}$ and $\mathrm{NaO}$ in some samples and their absence in others may be explained by their high mobilities and significant leaching during the kaolinitization process [42]. In the present study these low grades may be characteristic of refractory minerals such as kaolinite in the clay materials studied [23]. The low zero levels of $\mathrm{P}_{2} \mathrm{O}_{5}, \mathrm{MgO}$, and $\mathrm{MnO}$ may be related to the presence of accessory minerals [45]. These accessory minerals have not been identified by XRD. However, other more advanced methods may be used to determine them. Since $\mathrm{SiO}_{2}(46.14-55.39 \%)$, $\mathrm{Al}_{2} \mathrm{O}_{3}(25.21-34.88 \%)$ and $\mathrm{Fe}_{2} \mathrm{O}_{3}(15.22-19.37 \%)$ are the most abundant chemicals in clay materials of Baboutcheu-Ngaleu, it suggests that the significant quantities of $\mathrm{SiO}_{2}$ is the result of intervention of a neoformation in the study area and this is confirmed by the presence of newly formed clays such as kaolinite detected by XRDs. The ratio of $\mathrm{SiO}_{2} / \mathrm{Al}_{2} \mathrm{O}_{3}$ values greater than 01 would indicate an abundance of silica rather than alumina [42]. The values around (01) are characteristic of kaolinitic clays [25], whereas Pialy et al. [45] states that values around two (02) indicate a mixture of kaolinite/mica or illite. The High silica/alumina values would indicate the presence of kaolinite identified by XRD. On the other hand, $\mathrm{Fe}_{2} \mathrm{O}_{3} / \mathrm{Al}_{2} \mathrm{O}_{3}$ ratio is less than 1 in all samples, indicative of the presence of iron-based compounds. [4] alludes to the fact that these low values recall the presence of iron oxide and hydroxide such as hematite, goethite and ferryhydrite. Given the high percentage of goethite present in all samples as well as the low percentage of hematite, it would be preferable to attribute this to the presence of goethite in hematite. [45] suggests that the presence of variable proportion of Titanium oxide $\left(\mathrm{TiO}_{2}\right)$ is due to the presence of anatase, while Koneshloo [24] states that the high loss on ignition values would be due to the elimination of the water of constitution and the decomposition of certain associated minerals such as carbonates as well as the combustion of organic matter.

\section{Some possible areas of application of clays studied}

According to Sigg [47], in order to utilize clay for ceramic purposes, it must adhere to a certain particle size specification. The particle size composition plays an important part in the drying, shaping and firing characteristics of clay materials. In order to ascertain the suitability of the clay samples for ceramic applications, the particle size proportions were plotted on the Winkler [50] triangular diagram shown in Fig. 10. Consequently, four samples E1, E2, E3 and E4 were disqualified for solid brick making, while samples E4 and E5 were recommended for masonry tiles and bricks. From the mineralogy, kaolinite is the main clay mineral in the samples studied, which is also the most important mineral in the ceramics industry because of its refractory characteristics. The addition of feldspar would enhance the flux characteristics by promoting the appearance of a viscous phase during the heat treatment which contributes to reducing the porosity and improving the mechanical properties of clay products. From a geochemistry perspective, Table 7 presents the eligibility limits of clay for ceramic applications. Alumina which is another refractory material, whose recommended proportions vary between 9 and 45 , plays an important role in the plasticity of clays. Generally, the increase in alumina content improves the plasticity of the clays, which allows the ease of molding. The alumina contents obtained in the samples falls within the recommended eligibility limits. The silica contents acceptable for ceramic use (35-85\%) are close to those of the analyzed samples (46.14-55.3\%). Upon examination of Wrinkler 1954 diagram and the table of legibility limits, other suitable materials could be added to enlarge the sphere of utilization of the clay materials. 

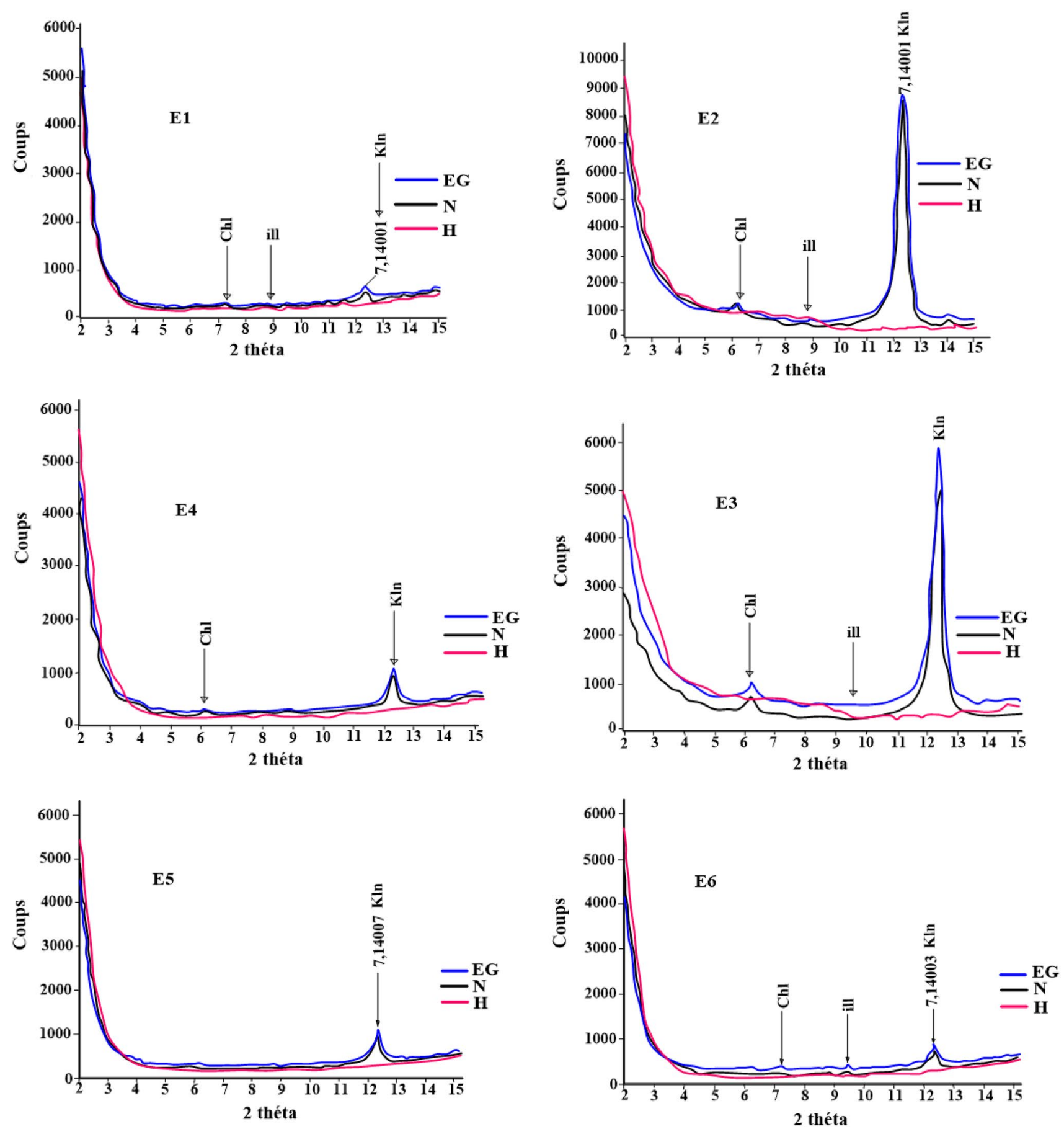

Fig. 9 Diffractogram of samples E1, E2, E3, E4, E5 and E6 obtained by XRD on clay fraction

Table 5 The proportion of different clay minerals present in the clay fraction

\begin{tabular}{llrrrrl}
\hline Minerals & E1 & E2 & E3 & E4 & E5 & E6 \\
\hline Kln & 45.83 & 82.3 & 79.82 & 80 & 100 & 46.1 \\
Chl & 13.69 & 6.19 & 7.89 & 20 & 0 & 13.77 \\
III & 40.47 & 11.15 & 12.28 & 0 & 0 & 40.11 \\
\hline
\end{tabular}

KIn kaolinite, Hem hematite, Ant anatase, Gbs gibbsite, At total clay, Qtz quartz, Ch/ Chlorite, Gt goethite, Fld feldspath, III illite 
Table 6 Geochemical composition of major elements in the samples in terms of percentage of oxides

\begin{tabular}{lllllll}
\hline Sample identification & $\mathrm{E} 1$ & $\mathrm{E} 2$ & $\mathrm{E} 3$ & $\mathrm{E} 4$ & E5 & E6 \\
\hline $\mathrm{SiO}_{2}$ & 47.86 & 46.93 & 48.99 & 46.14 & 55.39 & 48.23 \\
$\mathrm{TiO}_{2}$ & 1.97 & 1.65 & 1.54 & 1.66 & 1.67 & 1.47 \\
$\mathrm{Al}_{2} \mathrm{O}_{3}$ & 32.53 & 34.70 & 29.21 & 34.88 & 25.21 & 33.63 \\
$\mathrm{Fe}_{2} \mathrm{O}_{3}$ & 17.31 & 15.50 & 19.37 & 15.22 & 16.51 & 15.60 \\
$\mathrm{MnO}$ & 0.04 & 0.12 & 0.08 & 0.73 & 0.15 & 0.17 \\
$\mathrm{MgO}$ & 0.24 & 0.47 & 0.40 & 0.44 & 0.52 & 0.50 \\
$\mathrm{CaO}$ & 0.01 & 0.10 & 0.11 & 0.55 & 0.22 & 0.18 \\
$\mathrm{NaO}$ & 0 & 0 & 0.04 & 0 & 0.10 & 0 \\
$\mathrm{~K}_{2} \mathrm{O}$ & 0 & 0.47 & 0.23 & 0.27 & 0.19 & 0.19 \\
$\mathrm{P}_{2} \mathrm{O}_{5}$ & 0.011 & 0.02 & 0 & 0.07 & 0 & 0 \\
$\mathrm{TOTAL}$ & 100 & 100 & 100 & 100 & 100 & 100 \\
$\mathrm{LOI}_{\mathrm{SiO}} / \mathrm{Al}_{2} \mathrm{O}_{3}$ & 11.12 & 11.68 & 11.74 & 10.96 & 12.3 & 10.86 \\
$\mathrm{Fe}_{2} \mathrm{O}_{3} / \mathrm{Al}_{2} \mathrm{O}_{3}$ & 1.47 & 1.35 & 1.68 & 1.32 & 2.20 & 1.43 \\
\hline
\end{tabular}

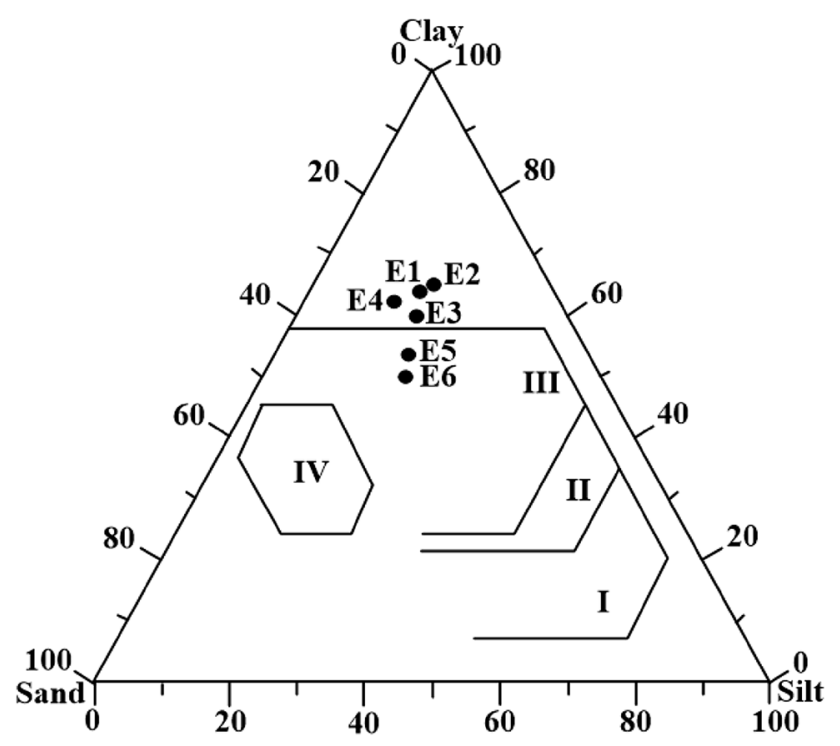

Fig. 10 Particle size of the samples plotted on the Winkler [50] diagram. Fields application: (I) solid bricks (II) multi-hole bricks, (III) masonry tiles and bricks, and (IV) hollow products

\section{Conclusion}

The main objective of the present study was to determine the physico-geochemical and mineralogical characterization of the clay materials of Baboutcheu-Ngaleu, in a bid to expand the catalogue of clay deposits for possible industrial or artisanal exploitation. To achieve this goal, we proceeded with two methods: field methods and laboratory methods. With regards to field work, it was a question of identifying the various facies present and characterizing them macroscopically. For this, different trial pits were made according to the so-called topo sequential method and samples were taken from the profiles of the trial pits. As a result, the color and the textures were determined. The laboratory physical analysis consisted in carrying out particle size analysis and determining the Atterberg limits by the Casagrande method. Then the mineralogical analysis by X-ray diffractometry on total powder and treatment on clay fraction under different conditions (normal, ethylene glycol and heating at $500^{\circ} \mathrm{C}$ ) were carried out. Finally the geochemical analysis of the samples were carried out by X-ray fluorescence. The particle size analysis shows the presence of the clay fraction in large proportions (52-64\%), the silty fraction in average proportions of (18-28\%) and the sandy fraction in a small proportions of (14-20\%). The Atterberg limits show that the clay materials studied are plastic clays, with plasticity characteristics varying between (14-45\%), and a plasticity index between (30-34.1\%). From the mineralogical point of view, the XRD reveals the presence of clay minerals such as kaolinite (45.83-100\%), chlorite (0-13.77\%) and illite (0-40.47\%) but also non-clay minerals such as goethite (17.16-21.76\%), gibbsite $(0.34-7.43 \%)$, hematite (3.76-10.35\%)), feldspar (4.45-13.37\%), quartz (2.74-10.22\%) and anatase (1.75-3.14\%).

On the geochemical level, the oxides present are $\mathrm{SiO}_{2}$ (46.14-55.39\%), $\mathrm{Al}_{2} \mathrm{O}_{3}$ (25.21-34.88\%), $\mathrm{Fe}_{2} \mathrm{O}_{3}$ (15.22-19.37\%), $\mathrm{TiO}_{2}(1.47-1.97 \%)$, and the alkalis $\left(\mathrm{K}_{2} \mathrm{O}\right.$ and $\mathrm{NaO}$ ), alkaline earth metals ( $\mathrm{MgO}$ and $\mathrm{CaO}$ ), $\mathrm{MnO}, \mathrm{P}_{2} \mathrm{O}_{5}$, the proportions of which are very low to trace. The proportions of $\mathrm{SiO}_{2}$ are abundant in all samples. The $\mathrm{SiO}_{2} / \mathrm{Al}_{2} \mathrm{O}_{3}$ values are greater than one in all samples, while the $\mathrm{Fe}_{2} \mathrm{O}_{3} / \mathrm{Al}_{2} \mathrm{O}_{3}$ ratios are less than 1 in all the samples studied. The clay in the study area is principally a kaolinite clay and based upon the Winkler diagram to ascertain their ceramic uses, four samples were disqualified for solid brick manufacture 
Table 7 Eligibility limits for ceramic application of clays

\begin{tabular}{llcl}
\hline Nature of elements & Formulation & Tolerance limits & Effect on finished product \\
\hline Silica & $\mathrm{SiO}_{2}$ & $35-85$ & $\begin{array}{l}\text { Refractory and adds on the mass } \\
\text { Alumina }\end{array}$ \\
$\mathrm{Al}_{2} \mathrm{O}_{3}$ & $9-45$ & $\begin{array}{c}\text { Refractory, improves mechanical } \\
\text { resistance, and gives a white } \\
\text { color }\end{array}$ \\
Magnesite & $\mathrm{MgO}$ & $0-5$ & $\begin{array}{l}\text { Porosity } \\
\text { Lime }\end{array}$ \\
Iron sesquioxide & $\mathrm{CaO}$ & $0-25$ & Porosity \\
Titanium oxide & $\mathrm{Fe}_{2} \mathrm{O}_{3}$ & $0-10$ & Reddish color, melting \\
Alkaline oxides & $\mathrm{TiO}_{2}$ & $0.3-2$ & Yellow color \\
Carbon dioxide & $\mathrm{NaO} \mathrm{K}_{2} \mathrm{O}$ & $1-5$ & Melting point \\
Sulfur trioxide & $\mathrm{CO}_{2}$ & $0-10$ & Volume \\
Combined water & $\mathrm{SO}_{3}$ & $0-4$ & Volume/toxicity \\
\hline
\end{tabular}

while two samples were recommended for masonry tiles and bricks production.

However we recommend further tests to be carried out to properly understand the clay microstructure as well as mechanical trial tests such as compressive strength, tensile test, water absorption and sound transmission to further confirm its wide applicability.

\section{Compliance with ethical standards}

Conflict of interest The authors declare that they have no conflict of interest.

\section{References}

1. ASTM D422 (2007) Standard Test Methods for particle-Size Analysis of Soil, ASTM International, West Conshohocken, PA, 2000. www.astm.org

2. ASTM D4318 (2000) Standard Test Methods for Liquid Limit, Plastic Limit, and Plasticity Index of Soils, ASTM International, West Conshohocken, PA, 2000. www.astm.org

3. Bitom D (1988) Organisation et évolution d'une couverture ferralitique en zone tropicale humide (Cameroun). Genèse et transformation d'ensemble ferrugineux indurés profonds. Thèse. Univ.Poitiers.164p.Multigr

4. Bomeni IY (2013) Caractérisation physico chimique, minéralogique et propriétés céramiques des matériaux argileux de Babountou, mémoire de master. Fac Science Univ Dschang.68p

5. Diko ML, Ekosse GE, Ayonghe SN, Ntasin EB (2011) Physical characterization of clayey materials from tertiary volcanic cones in Limbe (Cameroon) for ceramic applications. Appl Clay Sci 51(3):380-384

6. Djangang CN, Elimbi A, Melo UC, Nkoumbou C, Lecomte G, Yvon J, Bonnet JP, Njopwouo D (2007) Characteristics and ceramic properties of clays from Mayouom deposit (west Cameroon). Ind Ceram 27(2):79-88

7. Djangang $C N$, Elimbi $A$, Lecomte $G L$, Nkoumbou C, Soro J, Blanchart P, Bonnet JP, Njopwouo D (2008) Sintering of claychamotte ceramic composites for refractory bricks. Ceram Int 34(5):1207-1213
8. Djangang CN, Elimbi A, Lecomte GL, Soro J, Nkoumbou C, Yvon J, Blanchart P, Njopwouo D (2008) Refractory ceramics from clays of Mayouom and Mvan in Cameroon. Appl Clay Sci 39(1-2):10-18

9. Djangang CN, Lecomte G, Soro J, Elimbi A, Blanchart P, Njopwouo $D$ (2010) Elaboration de CéramiquesPoreuses à base de Sciure de Bois et de deuxArgiles du Cameroun. Annales de Chimie Science des Matériaux 34(1):1-16

10. Djangang CN, Kamseu E, Ndikontar MK, Lecomte GL, Soro J, Melo UC, Elimbi A, Blanchart P, Njopwouo D (2011) Sintering behaviour of porous ceramic Kaolin-Corundum composites: phase evolution and densification. Mater Sci Eng A $528: 8311-8318$

11. Durand JH (1983) Les sols Irrigables. Etude pédologique. Presses Universitaire de France. Agence de Coopération Culturelle et Technique

12. Dumort JC (1968) Notice explicative sur la feuille DoualaOuest avec carte géologique au 1/500000. Imprimerie nationale, Yaoundé, $\mathrm{p} 42 \mathrm{p}$

13. Elimbi A, Njopwouo D, Pialy P, Wandji R (2001) Propriétés des Produits de cuisson de deuxargileskaolinitiques de l'Ouest du Cameroun. Silic Ind 66(9-10):121-125

14. Elimbi A, Njopwouo D (2002) Firing characteristics of ceramics from the Bomkoulkaolinitic clay deposit (Cameroun). Tile Brick Int 18(6):364-369

15. Elimbi A, Yeugouo E, Nenwa J, Liboum, Njopwouo D (2003) Caractérisationschimiquesetminéralogiques de deuxmatériaux du gisementargileux de Bakong (Cameroun). Afr J Mater Miner 06(1):13-19

16. Elimbi A, Founyapté S, Njopwouo D (2004) Effets de la température de cuisson sur la composition minéralogique et les propriétés physiques et mécaniques de deuxmatériauxargileux de Bakong (Cameroun). Annales de Chimie Science des Matériaux 29(2):67-77

17. Elimbi A, Piakeu JC, Djangang CN, Njopwouo D (2011) Etude Dilatométrique et Thermique des Produits Crus et Cuits de trois nuances d'ArgilesKaolinitiques. Annales de la Faculté des Sciences, Université de Yaoundé I, SérieChimie 38(1):1-19

18. Kamseu E, Leonelli C, Boccaccini DN, Veronesi P, Miselli P, Pellacani G, Melo UC (2007) Characterization of Porcelain Compositions using two china Clays from Cameroon. Ceram Int 33(5):851-857

19. Kamseu E, Braccini S, Corradi A, Leonelli C (2008) Microstuctural Evolution during Thermal Treatment of three Kaolinitic Clays from Cameroon. Adv Appl Ceram 108(6):338-346 
20. Kamseu E, Rizzuti A, Miselli P, Veronesi P, Leonelli C (2009) Use of noncontact dilatometry for the assessment of the sintering kinetics during mullitization of three kaolinitic clays from Cameroon. J Therm Anal Calorim 3(98):757-763

21. Kamseu E, Rizzuti A, Leonelli C, Perera D (2010) Enhanced thermal stability in $\mathrm{K}_{2} \mathrm{O}$ metakaolin-based geopolymer concretes by $\mathrm{Al}_{2} \mathrm{O}_{3}$ and $\mathrm{SiO}_{2}$ fillers addition. J Mater Sci 7(45):1715-1724

22. Kamseu E, Leonelli C, Obonyo E (2011) Evolution of fired clay products: from origin to sustainable building ceramics. Int Ceram 3(4):221-225

23. Kouayep L, Kamgang Kabayene BV, Njopwouo D, Wouatong ASL (2012) Minéralogie et géochimie des matériaux d'altération du complexe de Bana (Ouest Cameroun): genèse et évolution. Sciene médecine Rev CAMES-série A 13(1):1-8

24. Koneshloo M (2007) Caractérisation, estimation et valorisation des gisements d'argile kaolinitique du bassin des Charentes. Engineering Sciences (physic). Ecole normale superieuredes mines de Paris, 2007. French. <NNT: 2007ENMP1486

25. Kwopnang NRM (2016) Caractérisation et valorisation des argiles de Njimom, Founmban. Mémoire de master, faculté des sciences, Université de Liège

26. Lemougna PN, Mackenzie JDK, Melo UC (2011) Synthesis and thermal properties of inorganic polymers (geopolymers) for structural and refractory applications from volcanic Ash. Ceram Int 37:3011-3018

27. Leonelli C, Kamseu E, Melo UC, Corradi A, Pellacani GC (2008) Mullitisation Behavior during thermal treatment of three kaolinitic clays from Cameroon: densification, sintering kinetic and microstructure. Int Ceram 57(6):396-401

28. Mbey JA, Hoppe S, Thomas F (2012) Cassava starch-kaolinite composite film. Effect of clay content and clay modification on film properties. Carbohydr Polym 88(1):213-222

29. Melo UC, Kamseu E, Djangang C (2003) Effects of fluxes on the fired properties between 950 and $1050 \mathrm{C}$ of some Cameroonian clays. Tile Bricks Int 19(6):384-390

30. Millot G (1964) Géologie des argiles: Altérations, Sédimentologie, Géochimie. Masson et Cie, Paris, p 35

31. Moore DM, Reynolds RC Jr (1989) X-ray diffraction and the identification and analysis of clay minerals. Oxford University Press, Oxford, $\mathrm{p} 332 \mathrm{p}$

32. Munsell Soil Color (1975) Charts. Macbeth. Division of kallmorge, corporation. 2441 nord Calvert street Baltimore Maryland. 21218

33. Njopwouo D (1984) Minéralogie et physico-chimie des argiles de Bamkoul et de Balengou (Cameroun). Utilisation dans la polymérisation du styrène et dans le renforcement du caoutchouc naturel. Thèse Doct d'Etat, Univ Yaoundé Cameroun

34. Njopwouo D, Roques G, Wandji R (1987) A contribution to the study of the catalytic action of clays on the polymerisation of styrene: I-charaterization of polystyrenes. Clay Miner 22(1):145-156

35. Njopwouo D, Wandji R (1988) Minéralogieetcomportement de quelques argiles camerounaises au renforcement du caoutchouc naturel par voie humide. Annales de la Faculté des Sciences, Université de Yaoundé I, SérieChimie 2(1-2):187199

36. Njopwouo D, Roques G, Wandji R (1988) A contribution to the study of the catalytic action of clays on the polymerisation of styrene: reaction mechanism. Clay Miner 23(1):35-43
37. Njopwouo D, Wandji R (1982) Un gisement d'halloysite à Balengou (Ouest-Cameroun). Revue Scientifiqueet Technique, Série Science de la Terre 2:41-54

38. Nkoumbou C, Njopwouo D, Villiéras F, Njoya A, Yonta GC, Ngo Njock L, Yvon J, Tchoua FM (2006) Geological study and physicochemical Characteristics of Talc of Boumnyebel (Centre-Cameroon). J Afr Earth Sc 54:61-73

39. Nkoumbou C, Villiéras F, Barres $O$, Bihannic I, Pelletier M, Razafitianamaharavo A, Metang V, Yonta Ngoune C, Njopwouo D, Yvon J (2008) Physicochemical properties of talc ore from Pout-kelle and Memel deposits (central Cameroon). Clay Miner 43(2):317-337

40. Njopwouo D, Wandji R (1982) Un gisement d'halloysite à Balengou (Ouest-Cameroun). Revue Scientifique et Technique, Série Science de la Terre 2:41-54

41. Njoya A, Ekodeck GE, Nkoumbou C, Njopwouo D, Tchoua MF (2001) Matériaux argileux au Cameroun: gisement et exploitation. Actes de la première conférence sur la valorisation des matériaux argileux au Cameroun

42. Njoya A, Nkoumbou C, Grosbois C, Njopwouo D, Njoya D, Courtin AN, Yvon J, Martin F (2006) Genesis of Mayouom kaolin deposit (Western Cameroon). Appl Clay Sci 32(1-2):125-140

43. Nono A, Likeng JDH, Wabo H, Tobue Biaya S (2009) Influence de la nature Lithologique et des structures géologiques sur la qualité est la dynamique des eaux souterraines dans les hautes terres de l'Ouest-Cameroun. Int J Biol Chem Sci 3(2):218-239

44. Obonyo E, Kamseu E, Melo UC, Leonelli C (2011) Advancing the use of secondary inputs in geopolymer binders for sustainable cementitious composites. Rev Sustain 2(3):410-423

45. Pialy P, Tessier-Doyen N, Njopwouo D, Bonnet JP (2009) Effects of densification and mullitization on the evolution of the elastic properties of a clay-based material during firing. J Eur Ceram Soc 29(9):1579-1586

46. Rotenberg B (2007) Modélisation multi-échelles du comportement de l'eau et ions dans les argiles. Thèse de Doctorat de I'Université de Paris 6, France

47. Sigg J (1991) Les produits des terres cuites. Septima, Paris, p $423 p$

48. Tchakoute HK, Elimbi A, Mbey JA, NgallySabouang CJ, Njopwouo D (2012) The effect of adding alumina-oxide to metakaolin and volcanic ash on geopolymer products: a comparative study. Constr Build Mater 35:960969

49. Tchakoute HK, Elimbi A, DiffoKenne BB, Mbey JA, Njopwouo D (2013) Synthesis of geoplymers from volcanic ash via alkaline fusion method: effect of $\mathrm{Al}_{2} \mathrm{O}_{3} / \mathrm{Na}_{2} \mathrm{O}$ molar ratio of soda-volcanic ash. Ceram Int 39(1):269-276

50. Winkler HGF (1954) Bedeutung der Korngrossenverteilung und des Mineralbestandes von Tonen fur die Herstellung grobkeramischer Erzeugnisse. Ber Dtsch Keram Ges 31:337-343

Publisher's Note Springer Nature remains neutral with regard to jurisdictional claims in published maps and institutional affiliations. 